\title{
地震時の液状化事例とせん断波速度の関係 \\ CORRELATION BETWEEN SOIL LIQUEFACTION DURING EARTHQUAKE AND SHEAR WAVE VELOCITY
}

\author{
鈴木康 嗣*, 時松孝次** \\ Yasutsugu SUZUKI and Kohji TOKIMATSU
}

\begin{abstract}
The seismic CPT tests are conducted at 66 sites where soil liquefaction have or have not occurred during earthquakes. The correlations among the cyclic shear stress ratio, modified shear wave velocity $\mathrm{V}_{\mathrm{s} 1}$, soil behavior type index $\mathrm{I}_{\mathrm{c}}$ and the actual soil performance during earthquakes are examined. The critical $V_{s 1}$-value causing liquefaction for sand is found to increase with $I_{c}$ if $I_{c}<1.9$, while it decreases if $I_{c}>1.9$. Based on the above relation, the boundary line separating liquefiable from non-liquefiable conditions is presented in terms of $V_{s 1}$ and $I_{c}$, which is uniquely expressed regardless of the fines content.
\end{abstract}

\author{
Keywords: Shear wave velocity, Liquefaction resistance, Case history, Cone penetration test, Soil classification, \\ Earthquake damage, Strong motion record \\ せん断波速度, 液状化強度, 事例検討, コンン貫入試験, 土質分類, 地震被害, 強震記録
}

1.はじめに

砂地盤の液状化強度を原位置試験から評価する手法として，標準 貫入試験(SPT)のN值が広く用いられている ${ }^{1)}$ ，2)。標準貫入試験は, 簡易な装置で地盤の動的強度が得られることから, 液状化予測に適 した試験法であるが，細粒分を多く含む土や碩を含む土に対する適 用性には限界がある。そこで，標準貫入試験以外の原位置調查手法

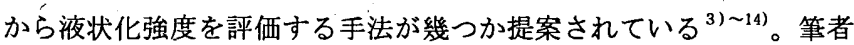
らは，細粒分を含むシルト質砂に適していると考えられるコーン貫 入試験 (CPT) に基づく液状化強度予測の可能性を既に報告してい $ろ^{3), 4)}$ 。一方, 磁を含む土に対しては, 標準貫入試験を大型化した 大型貫入試験 (LPT) ${ }^{5)}$ や，せん断波速度 (せん断弾性係数 ${ }^{6)}{ }^{614)}$ が適 していると考えられ，せん断波速度に関しては室内液状化試験 ${ }^{6) ~ 8) ~}$ や地震時の液状化事例 ${ }^{9) \sim 14)}$ との関係が示されている。

砂質土の液状化強度の評価法として現在最も信頼できる方法は, 原位置凍結サンプリング15)により採取した真に乱さない試料を用い て, 繰返し三軸試験等により液状化強度を求める手法である。時松 $ら^{63,7)}$ は砂質土に関して凍結サンプリング試料の液状化強度とせん断 弹性係数の関保について検討 ${ }^{6}$ すすると共に, 歪履歴を与えてせん断 弾性係数を合わせることで, 室内調整試料に関してもせん断弾性係 数で液状化強度を評価できることを示した ${ }^{7)}$ 。また, 畑中ら ${ }^{8)}$ は礫を
含む土に関して凍結サンプリング試料の液状化強度とせん断波速度 の関係を示した。しかし, 絽返し三軸試験から得られる液状化強度 は, 原位置の応力状態や地震動の多方向性・不規則性の影響を考慮 していないので，実際の地震時における液状化の有無との対比 ${ }^{16)}$ が 重要である。せん断波速度を用いた既往の手法でも, 実際の地震時 における液状化の有無に基づいて液状化判定図表を作成してい $3^{9) \sim 14)}$ 。Andrusら ${ }^{14)}$ は，26地震・70以上のサイトで行われたせん断 波速度測定結果を収集し, 判定図表を作成しているが, 大地震時の データが少ないため, 液状化強度が大きい場合や細粒分を多く含む 場合には適用性に欠ける部分がある。

本研究では, 強震記録と液状化事例がそろっている地域において サイスミックコーン貫入試験 (SCPT) を実施 ${ }^{4)}$ し，先端抵抗と周面摩 擦抵抗を組合わせて土質分類を行い, せん断波速度と地震外力の比 較を行った。その結果に基つきき,SCPT試験のせん断波速度から液状 化強度を予測する可能性を検討する。

\section{2. サイスミックコーン貫入試験}

\section{1 試験の概要}

表 1 に示す各地震において強震記録と液状化事例が揃っている66 地点でサイスミックコーン貫入試験を実施した。表 1 では, 磁を含
* 鹿島技術研究所建箖構造グループ 上席研究員・工修

** 東京工業大学大学院理工学研究科建築学専攻 教授. 工博
Supervisory Research Eng., Building Structure Group, Kajima Technical Research Institute, Kajima Corp., M. Eng.

Prof., Dept. of Architecture and Building Engineering, Faculty of Eng., Tokyo Institute of Technology, Dr. Eng. 
む土層が存在する地点（神戸市のポートアイランドと六甲アイラン ドの全地点, 以後対象土を䃯混じり土と呼称）と，存在しない地点 （それ以外，以後砂質土と呼称）を区別している。

試験に用いたコーン貫入体（図 1) は，先端抵抗，周面摩摖抵 抗，間隙水圧を測定する一般的な 3 成分コーンに，せん断波を測定 する速度計を組込んだサイスミックコーン ${ }^{17)}$ である。SCPT試験は専 用の調查車 ${ }^{18)}$ を用いて $2 \mathrm{~cm} / \mathrm{s}$ の一定速度でコーンを貫入しながら， $2.5 \mathrm{~cm}$ 間隔で上記 3 成分を測定した。また, $50 \mathrm{~cm}$ または $100 \mathrm{~cm}$ 毎に 貫入を一時停止し，調查車下部に設置されている板吅き装置 ${ }^{18)}$ によ り地表で発生させたせん断波を測定するとともに，途中の 1 深度で 間隙水圧が消散して静水圧になるのを待って地下水位を測定した。

板吒き装置には機械的なハンマーを用いているので，立上がりが 明瞭で再現性が非常に良いせん断波を発生できる。そのため，人為

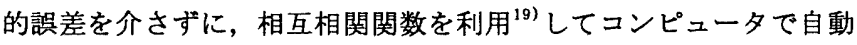
的にせん断波の時間差を算出した。

\section{2 試験結果と土質分類}

SCPT試験結果の一例を図 2 に示す。図 2 には, 先端抵抗 q , 周 面摩擦抵抗 $\mathrm{f}_{\mathrm{s}}$, 間隙水圧 $\mathrm{P}_{\mathrm{w}}$, 後述する $\mathrm{I}_{\mathrm{c}}$, せん断波測定波形, せ ん断波速度 $\mathrm{V}_{\mathrm{s}}$ の染度分布と共に, 液状化したと判断した深度の範囲 と 3 章以降の検討に採用したデータの深度を示している。また, 間 隙水圧の哚度分布中には，間隙水圧の消散測定から得られた静水圧 $\mathrm{P}_{\text {wo }}$ の深度分布を破線で併記した。せん断波の波形は立ち上がりが 明瞭なため，測定を行った $50 \mathrm{~cm}$ 間隔でせん断波速度を評価した。

SCPT試験では直接土を観察することが出来ない。Robertsonは，先 端抵抗 $q_{1}(\mathrm{kPa})$ と, 周面摩擦抵抗 $\mathrm{f},(\mathrm{kPa})$ と先端抵抗 $\mathrm{q}_{\mathrm{t}}$ の比であ る摩暩比 $\mathrm{R}_{\mathrm{f}}\left(=\mathrm{f}_{\mathrm{s}} / \mathrm{q}_{\mathrm{t}}\right)$ を上載圧で基準化した基準化先端抵抗 $\mathrm{Q}_{\mathrm{t}}$ と基準化摩擦比 $\mathrm{F}_{\mathrm{R}}$ を定義 ${ }^{20)} \mathrm{L}$, 両者から土質を一つの数值で分類す

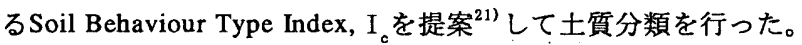

$$
\begin{aligned}
& \mathrm{Q}_{\mathrm{t}}=\left(\mathrm{q}_{\mathrm{t}}-\sigma_{\mathrm{v}}\right) / \sigma_{\mathrm{v}}, \\
& \mathrm{F}_{\mathrm{R}}=\mathrm{f}_{\mathrm{s}} /\left(\mathrm{q}_{\mathrm{t}}-\sigma_{\mathrm{v}}\right) \times 100 \quad(\%) \\
& \mathrm{I}_{\mathrm{c}}=\left\{\left(3.47-\log \mathrm{Q}_{\mathrm{t}}\right)^{2}+\left(1.22+\log \mathrm{F}_{\mathrm{R}}\right)^{2}\right\}^{0.5}
\end{aligned}
$$

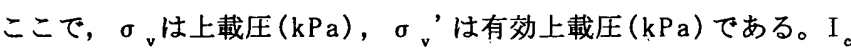
は, 粘性土の先端抵抗が砂質土に比へて小さくなる性質や, 粘性土 は粘着力の影響で砂質土に比べて摩摖比が大きくなる性質を利用し て土質分類を行う指標で，砂質士に比べて粘性土の方が大きな值と
なる。上記の関係は主に北米のデータに基づいて作成されたもので あるが，堆積環境が異なる日本の土にも適用可能であることを筆者 らが確認している ${ }^{22)}$ 。また, 筆者らは(3) 式をさらに進め, I $\mathrm{I}_{\mathrm{c}}$ から細 粒分含有率FC (\%) を推定するために次式を提案した ${ }^{22)}$ 。

$$
F C=I_{c}^{4.2}
$$

図 2 には，(4)式から求めたFCに基づく柱状図を併記している。 $\mathrm{I}_{c}$ が 2.05 以下で砂，2.95以上で粘土，その中間をシルト系の土と判断 $\iota^{22)}, I_{c}=2.54$ でFC $=50 \%$ となる。

\section{3 試験地点の強震記録と液状化の有無}

SCPT試験は, 文献 4) に示した78地点で実施したが, 一部の地点 でせん断波速度を測定しなかったため, 表 1 に示す 66 地点のデータ を用いる。SCPT試験地点, 液状化の有無, 設定した最大水平加速度 $\alpha_{\max }$ およびその設定に用いた強震記録は文献 4) と同一であり，その 一覧を表 1 に示す。最大水平加速度は，地表 (一部建物内)における 強震記録 ${ }^{23) ~ 37)}$ の水平 2 成分をべクトル合成した最大值，または推定 された最大加速度值 ${ }^{38)}$ とした。

釧路沖地震および北海道東方沖地震で液状化の被害が生じた釧路 市内の液状化地点と非液状化地点を含む16地点でSCPT試験を実施し た。釧路沖地震では釧路地方気象台 ${ }^{23)}$. 24) と釧路港湾建設事務所 ${ }^{25}$ で, 北海道東方沖地震では上記 2 地点 ${ }^{24), 26), 27)}$ と共にESG研究会による 多地点の強震記録 ${ }^{28}$ が得られている。そこで, ESG研究会による強震 記録が得られている地点ではその記録を北海道東方沖地震の值と し，釧路市内ではSCPT試験を主に海岸付近で実施したことから，釧 路港湾建設事務所における両地震の最大加速度の比 $(452 / 274=$ 1.65)をESG研究会による観測値に乗じ，得られていない釧路沖地震 の最大加速度を推定した。また, ESG研究会による強震記録が得られ ていない地点では，文献38)で推定している釧路沖地震における最大 加速度を釧路沖地震の值とし, 北海道東方沖地震は上記の比の逆数 (1/1.65) を乗じた值とした。表 1 には両地震の最大值を併記してい る(括弧内に北海道東方沖地震)。

北海道南西沖地震では, 函館市の 6 地点, 上磯町の 2 地点, 長万 部町の 7 地点および森町の 2 地点でSCPT試験を実施し, 函館港湾建

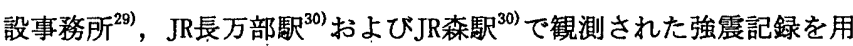
いた。

兵庫県南部地震では, 神戸市の 24 地点, 西宮市の 2 地点および尼

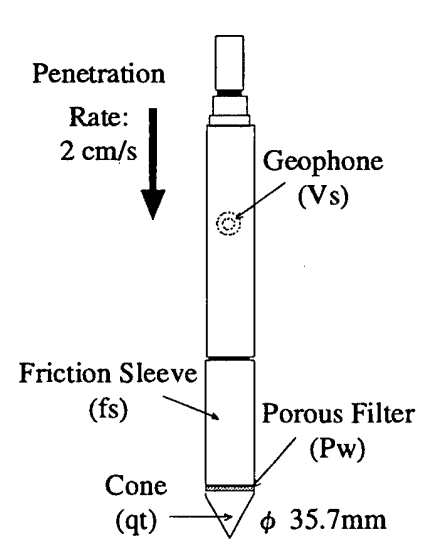

図 1 サイスミックコーンの概要
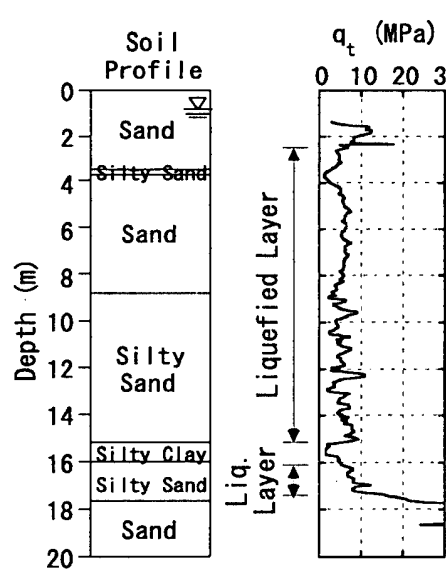

図 2
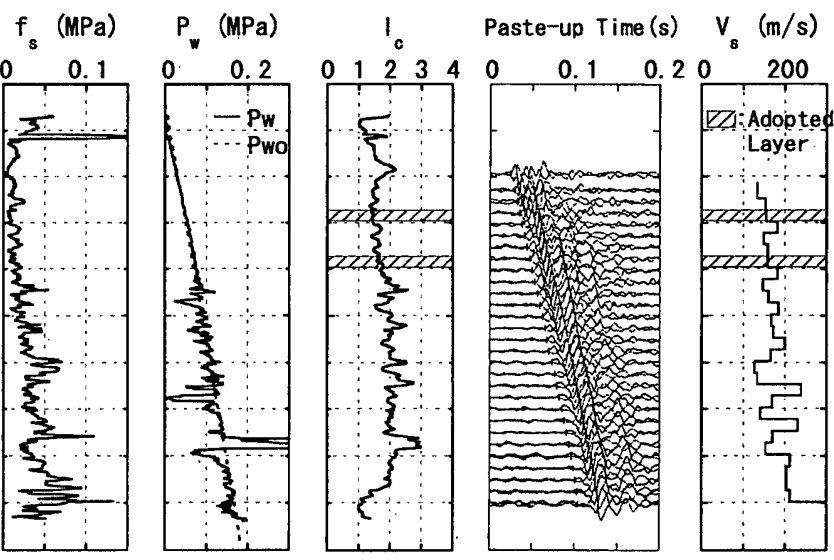

SCPT試験結果の一例（釧路東港, KEP） 
表 1 調查地点の液状化の有無と地震外力

\begin{tabular}{|c|c|c|c|c|c|c|c|c|c|c|}
\hline Test Regions & $\begin{array}{l}\text { Test } \\
\text { Codes }\end{array}$ & $\begin{array}{c}\text { Field } \\
\text { Behavior* }{ }^{*} \\
\end{array}$ & $\begin{array}{r}\text { Thickness of } \\
\text { Liq. Layer }(\mathrm{m}) \\
\end{array}$ & $\begin{array}{l}\text { Depths of Adopted Data (m) } \\
\text { Liq. / Boundary / No Liq. }\end{array}$ & $\begin{array}{c}\text { Sand or } \\
\text { Gravel }\end{array}$ & $\begin{array}{l}\text { Ref. of } \\
\text { CPT }\end{array}$ & Earthquakes & M & $\begin{array}{c}\alpha_{\max } \\
\left(\mathrm{cm} / \mathrm{s}^{2}\right)\end{array}$ & Reference of $\alpha_{\max }$ \\
\hline \multirow[t]{16}{*}{$\begin{array}{c}\text { Kushiro } \\
\text { City }\end{array}$} & $\overline{\mathrm{KPC}-\mathrm{A}}$ & $\mathbf{0}^{*}$ & \begin{tabular}{|c|}
3 \\
$(-)$
\end{tabular} & $\begin{array}{l}3.1 .3 .6 / / 6.1 \\
(/ 3.13 .6 / / 6.1)\end{array}$ & \multirow{16}{*}{$\begin{array}{c}\text { Sand } \\
\text { (Soil } \\
\text { without } \\
\text { Gravel) }\end{array}$} & & \multirow{16}{*}{\begin{tabular}{|c|} 
Kushiro-Oki \\
(01/15/1993) \\
(Hokkaido \\
Toho-Oki) \\
$(10 / 04 / 1994)$
\end{tabular}} & \multirow[t]{16}{*}{$\begin{array}{l}7.8 \\
(8.2)\end{array}$} & \multirow[t]{2}{*}{$452(274)^{22}$} & \multirow[t]{2}{*}{ 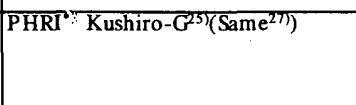 } \\
\hline & $\overline{\mathrm{KPC}-\mathrm{B}}$ & $\stackrel{\bullet}{(\triangle)}$ & $\begin{array}{c}4 \\
(-) \\
\end{array}$ & $\begin{array}{c}3.0 .4 .0 .6 .6 / / 7.6 \\
(/ 3.0 .4 .0,6.6 / 7.6)\end{array}$ & & & & & & \\
\hline & KFT & 9 & $\begin{array}{c}6 \\
(4) \\
\end{array}$ & $\begin{array}{l}6.1 .9 .6 / 12.6 / \\
(6.1 / 9.6 / 12.6)\end{array}$ & & & & & $300(180)$ & $1.65^{*}$ T oho-Oki(T BS by ESG $\left.{ }^{42}{ }^{28}\right)$ ) \\
\hline & KEP & $e(0)$ & $14(14)$ & $5.7 .7 .7 / /(5.7 .7 .7 / 1)$ & & & & & & \\
\hline & KMS & $0(0)$ & $-(-)$ & $/(10.5(/ 110.5)$ & & & & & $320(194)$ & $1.65^{*}$ T oho-Oki(KMB by ESG $\left.{ }^{28}\right)$ ) \\
\hline & ASS & $\Delta(\Delta)$ & $-(-)$ & $(2.6,3.1 /(12.6,3.1 /)$ & & & & & $530(320)$ & $1.65^{*}$ T oho-Oki(ASH by ESG ${ }^{28}$ ) \\
\hline & KSS & $\Delta(\Delta)$ & $-(-)$ & $/ 3.1,4.6 /(/ 3,1,4.6 /)$ & & & & & $270(163)$ & $1.65^{*}$ Toho-Oki(KKP by ESG $\left.{ }^{28}\right)$ \\
\hline & KNP & $\triangle(0)$ & $-(-2)$ & $8.0 / 11.5(/ 18.0 .11 .5)$ & & & & & $440(267)$ & $1.65^{*}$ Toho-Oki(SMZ by ESG $\left.{ }^{28}\right)$ \\
\hline & KIS & $0(0)$ & $-(-1)$ & $\frac{10.01 / 2.6(/ 2.6)}{/ / 2)}$ & & & & & & \\
\hline & $\mathrm{KCH}$ & $\Delta(0)$ & $-(-)$ & $\frac{14.6 /(1 / 4.6)}{14}$ & & & & & $380(228)$ & $1.65 *$ Toho-Oki(JSI by ESG( \\
\hline & $\mathrm{OSF}$. & $O(0)$ & $-(-)$ & $/ / 3,1(/ / 3,1)$ & & & & & $250(152)$ & $1.65^{*}$ T oho-Oki(KOS by ESG $\left.{ }^{28}\right)$ \\
\hline & KDB & $0(0)$ & $-(-)$ & $1 / 3.1(1 / 3.1)$ & & & & & $220(132)$ & $1.65^{*}$ T oho-Oki(TT R by ESG $\left.{ }^{28}\right)$ \\
\hline & TSS & $0(0)$ & $-(-)$ & $1 / 3.6(/ / 3.6)$ & & & & & & \\
\hline & KSP & $0(0)$ & $-(-)$ & $1 / 4.9(/ / 4.9)$ & & & & & $290(180)$ & Kurogane $^{38}\left(1 / 1.65^{*}\right.$ Kushiro-Oki) \\
\hline & $\overline{\mathrm{KTH}}$ & $\Delta(\Delta)$ & $-(-)$ & $(9.4 / 14.8(/ 9.4 / 14.8)$ & & & & & $160(100)$ & Otanoshike ${ }^{38}\left(1 / 1.65^{*}\right.$ Kushiro-OKi $)$ \\
\hline & KAA & Q(1) & $5(3)$ & $7.1 / 113.1(7.1 / / 13.1)$ & & & & & $190(120)$ & Mihara $^{38}\left(1 / 1.65^{*}\right.$ Kushiro-Oki) \\
\hline Hakodate & $\mathrm{HPC}$ & 0 & - & $1 / 2.1$ & Sand & & Hokkaido & 7.8 & 148 & Average value of PHRI \\
\hline City & HHS-A & a & 7 & $1.6 .4 .1 / \mathrm{I}$ & (Soil & & Nansei-Oki & & & Hakodate-F and Hakodate- $\mathbf{M}^{29)}$ \\
\hline & HHS-B & & $=$ & $14.6 / 2.1,8.2,8.7,12.2$ & without & & $(07 / 12 / 1993)$ & & & \\
\hline & HNP-A & - & 5 & $2.6 .4 .1 .5 .1 / 1 / 14.7$ & Gravel) & & & & & \\
\hline & $\overline{\mathrm{HNP}}-\mathrm{B}$ & $\Omega$ & 3 & $3.6 / / 7.6,19.3,21.7$ & & & & & 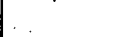 & \\
\hline & HNF & - & 8 & $\begin{array}{c}2.6 .4 .6 .5 .6 / / \\
8.1 .9 .113 .2\end{array}$ & & & & & & \\
\hline $\begin{array}{c}\text { Kamiiso } \\
\text { Town }\end{array}$ & HTF & - & 10 & $\begin{array}{l}3.1 .4 .1 .5 .1 / 1 \\
9.2 .13 .8 .19 .0\end{array}$ & & & & & & \\
\hline & HSB & 0 & - & $\begin{array}{c}/ / 5.1 .7 .1 .8 .1 .9 .2,11.2 \\
12.2,13.2,14.7,19.3\end{array}$ & & & & & & \\
\hline Oshamanbe & OSS & $\Delta$ & - & $/ 11.1 / 4.6,6.6,7.6$ & & & & & 298 & $\mathrm{RTR}^{\prime 3}$ JR Oshamanbe Station ${ }^{30)}$ \\
\hline Town & OTO & o & 3 & $3.6 / 10,7,12.2 / 8,2,9.2$ & & & & & & \\
\hline & $\begin{array}{ll}\text { OTH } \\
\text { OFS }\end{array}$ & 2 & 1 & $\mathrm{Non}^{* 7} / 10.3 .10 .8 / 5.7 .8 .2$ & & & & & & \\
\hline & OES & อ & 1 & $2.6 / / 6.6 .7 .6$ & & & & & & \\
\hline & OTG & 0 & $=$ & $1 / 3.6,4.1,5.7,6.7$ & & & & & & \\
\hline & OWC & $\Delta$ & - & $/ 3.6 .4 .6 / 2.6 .4 .1$ & & & & & & \\
\hline & ONS & 2 & 2 & $3.6,4.1 / /$ & & & & & & \\
\hline Mori Town & MWP-A & 2 & 10 & $3,6 / 1$ & & & & & 214 & RT RI JR Mori Station ${ }^{30)}$ \\
\hline & MWP-B & 0 & - & $/ / 2,6,5,1$ & & & & & & \\
\hline Kobe City & FUP & 0 & $=$ & $\frac{1 / 5.8}{1 / 8}$ & Sand & & Hyogoken- & 7.3 & 848 & $\mathrm{JMA}^{6} \mathrm{Kobe}^{31}$ \\
\hline & UES & 0 & - & 116.8 & (Soil & & Nanbu & & & \\
\hline & GOP & 0 & $=$ & $1 / 6.8$ & without & & $(01 / 17 / 1995)$ & & & \\
\hline & NAP & 0 & 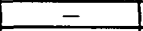 & $/ / 2,3,6.3$ & Gravel) & & & & & \\
\hline & TCF & ? & 8 & $5,1,5,6,7,1,7,6,8,1,11.6 / /$ & & & & & $\overline{412}$ & \begin{tabular}{|l} 
Higashikobe Bridge $^{22}$ \\
\end{tabular} \\
\hline & TKF & 2 & 11 & $5.6,9,0,11,0,14.0 / 18,6$ & & & & & & \\
\hline & NKO-A & 2 & 5 & $3,6,5,6,9,6, / 1$ & & & & & 521 & PHRI Kobe-ji- S $^{33)}$ \\
\hline & NKO-B & $\Omega$ & 4 & $5,1,6,1,6,6,7,1 / /$ & & & & & & \\
\hline & KOP & 2 & 4 & $3,3,5,3 / / 8,3,13,3$ & & & & & & \\
\hline & NPP & & 6. & $3,1,4,1,5,1 / 11.1 / 8.1,15.1$ & & & & & & \\
\hline . & $\mathrm{KMO}$ & 2 & 11 & $\frac{2.8,4.8,7.3 / 1}{2}$ & & & & & & \\
\hline & MIP & 2 & 3 & $4.3 / / 4.8,10.1$ & & & & & 743 & RTRI JR Takatori Station ${ }^{34)}$ \\
\hline & SHP & 0 & - & $1 / 4,3,8,3,15,8$ & & & & & & \\
\hline & SES & 0 & $=$ & $\frac{1 / 2.8,5.3}{2.3}$ & & & & & 834 & Osakagas Fukiai ${ }^{33)}$ \\
\hline & $\mathrm{HCP}$ & 0 & $=$ & $1 / 4,3,7,3,12,3$ & & & & & & \\
\hline & YKF & 0 & - & $\frac{1 / 3.1}{1 / 3}$ & Gravel & & & & 427 & Port Island ${ }^{35)}$ \\
\hline & KPS & e & 12 & $6.3 / / 17.8$ & (Soil & & & & & \\
\hline & SDC & e & 2 & $4.8 .6 .8 / 1$ & with & & & & & \\
\hline & KHS & $\triangle$ & $=$ & $/ 7,8,9,3,13,3,14,3 / 19.3$ & Gravel) & & & & & \\
\hline & KES & $\triangle$ & - & $16.8 / 8.3$ & & & & & & \\
\hline & $\mathrm{KWC}$ & - & 9 & $\begin{array}{r}4.8 .6 .8,8.3,9.8 \\
11.3 / / 13,8,19,3\end{array}$ & 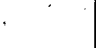 & & & & & \\
\hline & MHS & e & 4 & $2.8,4,3,8,8,11,8,14,3 / /$ & & & & & & \\
\hline & KAT & 0 & $=$ & $\frac{1 / 4.1}{14}$ & & & & & & \\
\hline & NWC & 2 & 2 & 3.811 & & & & & & \\
\hline Nishinomiya & HAH & ? & 5 & $4.1,4,6,6.6 / / 10,6$ & Sand & & & & 792 & Osakagas Nishinomiya a ${ }^{37}$ \\
\hline City & IES & - & 6 & $\begin{array}{l}4.1 .4 \cdot 6 \cdot 6 \cdot 1.7 .1 / \\
12.8 / 10.8 \cdot 14.8\end{array}$ & (Soil & & f & & & \\
\hline Amagasaki & SKF & $\Omega$ & 6 & $6.1 .7 .1 / 8.1 .11 .1 / 12.8$ & without & & & & 473 & PHRI Amagasaki-G ${ }^{33)}$ \\
\hline City & DMC & e & 4 & $7.1,7,6,9,6 / / 4,6,12,6,19,3$ & Gravel) & & & & 366 & Amagasaki No.3 Power Plant ${ }^{35}$ \\
\hline Yonago City & \begin{tabular}{|l} 
YAH-A \\
\end{tabular} & 2 & 3 & $3.8 / / 7.8$ & Sand & 46) & Tottoriken- & 7.3 & 441 & K-Net Yonago ${ }^{36)}$ \\
\hline & \begin{tabular}{|l|} 
YAH-B \\
\end{tabular} & 2 & 8 & $2.1,5.1,8.1 / 1$ & (Soil & & Seibu & & & \\
\hline Sakaiminato & YTK & 2 & 8 & $5.1 / / 9.1$ & without & & $(10 / 06 / 2000)$ & & 305 & PHRI Sakaiminato-G ${ }^{36}$ \\
\hline City. & YSA-A & 2 & 10 & $3.8 / 6.8 /$ & Gravel) & 47) & & & & \\
\hline & YSA-B & $\Omega$ & 8 & $3.3 / 5.9 /$ & & & & & & \\
\hline
\end{tabular}

崎市の 2 地点でSCPT試験を実施した。兵庫県南部地震では多数の強 震記録が锤測されているが，神戸海洋気象台 ${ }^{31)}$ ，東神戸大橋 ${ }^{32)}$ ，神戸 港工事事務所 ${ }^{33)}$ ，尼崎港工事事務所 ${ }^{33)}, \mathrm{JR}$ 鷹取駅 ${ }^{34)}$ ，ポートアイラン $ト^{35)}$, 関西電力尼崎第三発電所 ${ }^{35)}$, 大阪ガスの葺合供給部 ${ }^{35)} \cdot$ 西宮 $^{35)}$ で観測された強震記録を用いた。
鳥取県西部地震では，米子市の 2 地点と境港市の 3 地点でSCPT試 験を実施し，K-net米子 ${ }^{36}$ および境港湾空港工事事務所 ${ }^{37)}$ で観測され た強震記録を用いた。

図 2 に示したようなSCPT試験結果と，筆者らによる地震後の観察 (噴砂，地割れ，沈下等 ${ }^{39) \sim 43)}$ や文献 ${ }^{44), 45)}$ から，表 1 に示すように調 
查地点の液状化の有無と液状化層厚などを判断した ${ }^{4)}$ 。噴砂や周辺 建物との間に $5 \mathrm{~cm}$ 程度以上の沈下が確認された地点を液状化地点, 噴砂は確認されなかったが $5 \mathrm{~cm}$ 程度以下の沈下や地割れが確認され た地点を境界地点，いずれも確認できなかった地点を非液状化地点 と判断した。また, 液状化層や境界層の範囲は, 地表の沈下量と コーン貫入試験結果から推定した。図 2 の例では，地表の沈下量は $50 \sim 60 \mathrm{~cm}$ であり, 液状化による体積減少を 3 〜 5 と仮定すると液 状化層厚は10〜20m となる。そこで，梁度 $2.5 \sim 15.2 \mathrm{~m} ， 16.0$ 〜 $17.5 \mathrm{~m}$ の範囲（層厚約 $14 \mathrm{~m}$ ）を液状化層と推定した。ただし, 液状 化層厚の推定誤差が大きいので，最も液状化の可能性が高いと推定 される 2 深度のみを検討データに採用した。検討データは全てせん 断波速度を測定した $50 \mathrm{~cm}$ 区間（一部 $100 \mathrm{~cm}$ 区間）であり，その中心 深度は表 1 に示すとおりである。

\section{3. 地震外力とせん断波速度の比較}

\section{1 絽返しせん断応力比と換算せん断波速度の設定}

地震時において地盤内に生じる繰返しせん断応力比 $\tau_{d} / \sigma_{v}$ 'を次 式 ${ }^{1116)}$ で定義した。

$$
\frac{\tau_{\mathrm{d}}}{\sigma_{\mathrm{v}}^{\prime}}=\mathrm{r}_{\mathrm{n}} \frac{\alpha_{\mathrm{aax}}}{\mathrm{g}} \frac{\sigma_{\mathrm{v}}}{\sigma_{\mathrm{v}}^{\prime}}(1-0.015 \mathrm{z})
$$

ここで, $\mathrm{r}_{\mathrm{n}}: 0.1(\mathrm{M}-1), \mathrm{M}:$ 地震のマグニチュード, $\alpha_{\operatorname{ax}}$ : 地表 面最大加速度 $\left(\mathrm{cm} / \mathrm{s}^{2}\right), \mathrm{g}:$ 重力加速度 $\left(\mathrm{cm} / \mathrm{s}^{2}\right), \sigma_{\mathrm{v}}:$ 全上載圧 $(\mathrm{kPa}) ， \sigma_{v}^{\prime}$ : 有効上載圧 $(\mathrm{kPa}), \mathrm{z}$ : 地表からの染度 $(\mathrm{m})$ である。 地表面最大加速度 $\alpha_{\operatorname{axx}}$ と地震のマグニチュードMは，表 1 に示した 值を用いた。

せん断波速度 $\mathrm{V}_{\mathrm{s}}$ はN 值と同様に有効上載圧 $\sigma_{\text {、 }}$ 'の影響を受けるた め, 同じ液状化強度の土でも有効上載圧 $\sigma_{\mathrm{v}}{ }^{\prime}$ が大きくなるとせん断 波速度 $\mathrm{V}_{\mathrm{s}}$ が大きくなる。そこで, せん断波速度 $\mathrm{V}_{\mathrm{s}}(\mathrm{m} / \mathrm{s})$ から次式に 従って有効上载圧 $\sigma_{v}^{\prime}(\mathrm{kPa})$ の影響を換算した換算せん断波速度 $\mathrm{V}_{s 1}$ （m/s）を定義した。

$$
\mathrm{V}_{\mathrm{s} 1}=\mathrm{V}_{\mathrm{s}} /\left(\sigma_{\mathrm{v}}^{\prime} / 98\right)^{\mathrm{n}}
$$

ここで，nは指数である。 $\mathrm{n}$ の值については $0.25 〜 0.375$ の提案も ある ${ }^{7) .8)}$ が，砂質土に通常用いられている0.25を採用した。

\section{2 換算せん断波速度, 繰返しせん断応力比と $\mathrm{I}_{c}$ の関係}

地震時に地盤内に生じる綝返しせん断态力比 $\tau_{d} / \sigma_{\text {。' }}$ と換算せん 断波速度 $\mathrm{V}_{\mathrm{s} 1}$ の関係を，表 1 に示した砂質土（礫を含まない土， Sand）と礫混じり土（Grave1）を区別して図 3に示す。液状化した と判断された黒塗のデータが左側に集中する傾向はあるものの, 液 状化・非液状化の境界線を引くことは難しい。これは, 同じ換算せ ん断波速度 $V_{s 1}$ でも土の種類, すなわち細粒分含有率や平均粒径に よって液状化強度が異なる影響を無視しているためと考えられる。

SCPT試験から土質分類を行う指標として，（3）式で定義されるI。 がある。そこで, 換算せん断波速度 $\mathrm{V}_{\mathrm{s} 1}$ と $\mathrm{I}_{c}$ の関倸を, 砂質土と磁混 じり土を区別して図 4 に示す。液状化したと判断された黒塗のデー 夕は, $I_{c}$ が2.5以下の領域に分布している。これは, $I_{c}$ がある一定值 を越えると繰返しせん断态力比に関わらず液状化しない限界值が存 在することを示している。すなわち, 液状化が生じない粘性土と生 じる砂質土の境界に対応している。しかし，筆者らが示した換算先

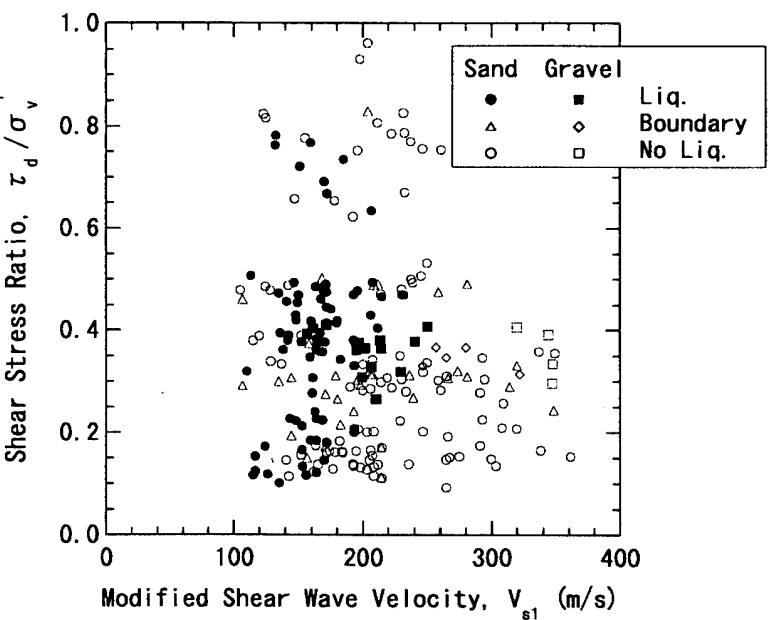

図 3 絽返しせん断応力比と換算せん断波速度の関係

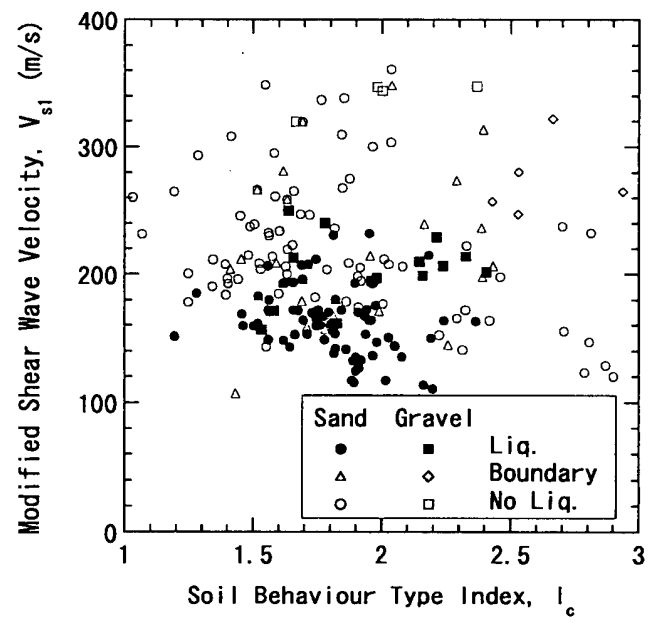

図 4 換算せん断波速度と $\mathrm{I}_{c}$ の関倸

端抵抗と $I_{c}$ の関倸 4 のような明確な傾向は認められず，図 4 の関保か ら液状化・非液状化の境界を議論するのは難しいと考えられる。

そこで, 図 3 , 図 4 の関係をさらに詳しく吟味するため, 筆者ら が提案したせん断波速度と先端抵抗の相関関俰, および先端抵抗を 用いた液状化強度予測式を用いて，以後の議論を進める。

\section{3 せん断波速度と先端抵抗の換算}

筆者らは, サイスミックコーン貫入試験の先端抵抗 $\mathrm{q}_{\mathrm{t}}(\mathrm{MPa})$ とせ ん断波速度 $\mathrm{V}_{s}(\mathrm{~m} / \mathrm{s})$ の関係を， $\mathrm{I}_{\mathrm{c}}$ を介して次式で定義した ${ }^{22)}$ 。

$$
\mathrm{V}_{\mathrm{s}}=\left(46.0 \mathrm{I}_{\mathrm{c}}-5.0\right) \mathrm{q}_{\mathrm{t}}^{0.4}
$$

また, 液状化・非液状化の境界線の換算先端抵抗 $\mathrm{q}_{\mathrm{t} 1}(\mathrm{MPa})$ を $\mathrm{I}_{c}$ で補 正した補正先端抵抗 $q_{\mathrm{ta}}(\mathrm{MPa})$ を次式で定義した ${ }^{4)}$ 。

$$
\begin{aligned}
& \mathrm{q}_{\mathrm{ta}}=\mathrm{q}_{\mathrm{t}}\left\{1+\mathrm{F}\left(\mathrm{I}_{\mathrm{c}}\right)\right\} \\
& \mathrm{q}_{\mathrm{t} 1}=\mathrm{q}_{\mathrm{t}} /\left(98 / \sigma_{v}^{\prime}\right)^{0.65} \\
& F\left(I_{c}\right)=\left(I_{c}-1.55\right) /\left(2.60-I_{c}\right) \\
& \left(1.55<\mathrm{I}_{c} \leqq 2.50\right) \\
& =0 \quad\left(I_{c} \leqq 1.55\right)
\end{aligned}
$$

ここで， $\sigma_{v}{ }^{\prime}$ は有効上載圧 $(\mathrm{kPa})$ である。補正関数 $\mathrm{F}\left(\mathrm{I}_{\mathrm{c}}\right)$ は, $I_{c}$ が 2.6 に近づくと急激に大きくなるが，I。が2.5以上で液状化事例がな 
いので，(8) 式は $\mathrm{I}_{\mathrm{c}}<2.5$ 範囲で成り立つ関係としている。

(7) 式の $\mathrm{q}_{\imath}$ に(8) 式の $\mathrm{q}_{11}$ を代入することで, 換算先端抵抗 $\mathrm{q}_{11}$ (MPa) による液状化・非液状化の境界線を, 換算せん断波速度 $\mathrm{V}_{\mathrm{s} 1}(\mathrm{~m} / \mathrm{s})$ による境界線に変換することが出来る。すなわち,

$$
\mathrm{V}_{\text {sicr }}=\left(46.0 \mathrm{I}_{\mathrm{c}}-5.0\right)\left[\mathrm{q}_{\mathrm{ta}} /\left\{1+\mathrm{F}\left(\mathrm{I}_{\mathrm{c}}\right)\right\}\right]^{0.4}
$$

ここで, $\mathrm{V}_{\mathrm{s} 1 \mathrm{cr}}(\mathrm{m} / \mathrm{s})$ は液状化・非液状化の境界線の換算せん断波速度 (限界換算せん断波速度)である。

なお，換算先端抵抗は有効上載圧の0.65乗に依存する ${ }^{4)}$ としてい るが，(7) 式でせん断波速度に变換する場合, 先端抵抗は 0.4 乗さ れ, 指数は $0.65 \times 0.4=0.26 \div 0.25$ となり, 換算せん断波速度が有 効上載圧力の 0.25 乗に依存するとした(6) 式の関俰と矛盾しない。

\section{$3.4 \mathrm{I}_{\mathrm{c}}$ で分類した繰返しせん断応力比と換算せん断波速度の関係} 限界換算せん断波速度 $\mathrm{V}_{\mathrm{sicr}}$ と $\mathrm{I}_{\mathrm{c}}$ の関係を検討するため, 図 3 に示し た繰返しせん断応力比 $\tau_{\mathrm{d}} / \sigma_{\text {v }}$ '換算せん断波速度 $\mathrm{V}_{\mathrm{s} 1}$ の関係を $\mathrm{I}_{\mathrm{c}}$ が (a) 1.55 以下, (b) $1.55 \sim 1.75$, (c) $1.75 \sim 2.00$, (d) $2.00 \sim$ 2.25 , (e) $2.25 \sim 2.60$, (f) 2.60 以上に分けて図 5 に示す。図 5 に は，（11）式により定義した液状化・非液状化の境界線を併記した。 図 5 より，砂質土のデータ（図 5 中のの， $\Delta, 0$ )を $\mathrm{I}$ 。で分類する と, 液状化・非液状化のデータが明瞭に別れ， $I_{c}$ が2.6以上で液状化 したと判断されたデータ(の)は存在しない。また, 液状化・非液状 化の境界線 (図 5 中の実線) は， I が，I。が1.9を境にして逆に左側へ移動し， I が2.6以上では縦軸と 一致している。以上の関係より, 砂質土に関しては, 液状化・非液
状化の事例データ:と境界線は概ね矛盾していないと判断される。し かし, 磁混じり土の液状化データ（図 5 中の四) は, 全体的に境界線 付近に分布し，実線で示した境界線と整合していない。

\section{5 繰返しせん断応力比で分類した換算せん断波速度と $I_{c}$ の関係}

図 5 より, 液状化・非液状化の境界線の換算せん断波速度 $\mathrm{v}_{\text {sicr }}$ は, $I_{c}$ が1.9を境にして増減することが分かった。そこで，この関係をさ らに詳細に検討するため, 図 4 に示した換算せん断波速度 $\mathrm{V}_{\mathrm{s} 1}$ と $\mathrm{I}_{c}$ の 関係を繰返しせん断応力比 $\tau_{\mathrm{d}} / / \sigma_{v}{ }^{\prime}$ が (a) 0.15 以下，(b) $0.15 \sim$ 0.20 , (c) $0.20 \sim 0.30$, (d) $0.30 \sim 0.40$, (e) $0.40 \sim 0.50$, (f) 0.50 以上に分けて図 6 に示す。図 6 には，(11) 式により定義した液 状化・非液状化の境界線を基に作成した換算せん断波速度 $\mathrm{V}_{\mathrm{s} 1}$ と $\mathrm{I}_{\mathrm{c}}$ の 関保における境界線 (繰返しせん断応力比一定線)を併記した。図 6 より, 砂質土のデータ（図 6 中のの， $\Delta ，$ ）を繰返しせん断応力比 で分類すると, 液状化・非液状化のデータが比較的明瞭に別れるこ とが分かる。液状化・非液状化の境界線 (図 6 中の実線) は, $I_{c}$ が 1.9 付近で最大值をとり, I が2.5程度を超えると換算せん断波速度が急 激に小さくなり，I $\mathrm{I}_{\mathrm{c}}$ が2.6でゼロとなる。砂質土に関しては, 液状 化 - 非液状化の事例データと（11）式から得られる境界線は概放矛盾 しないと判断される。しかし, 図 5 と同様に磷混じり土の液状化 データ（図 6 中のШ) は全体的に境界線付近に分布し，境界線と整合 していない。

以上の結果より, 砂質土の液状化・非液状化の境界線は，(11）式 で定義すれば良いと判断される。しかし，礫混じり土に関してはさ らに検討が必要と考えられる。
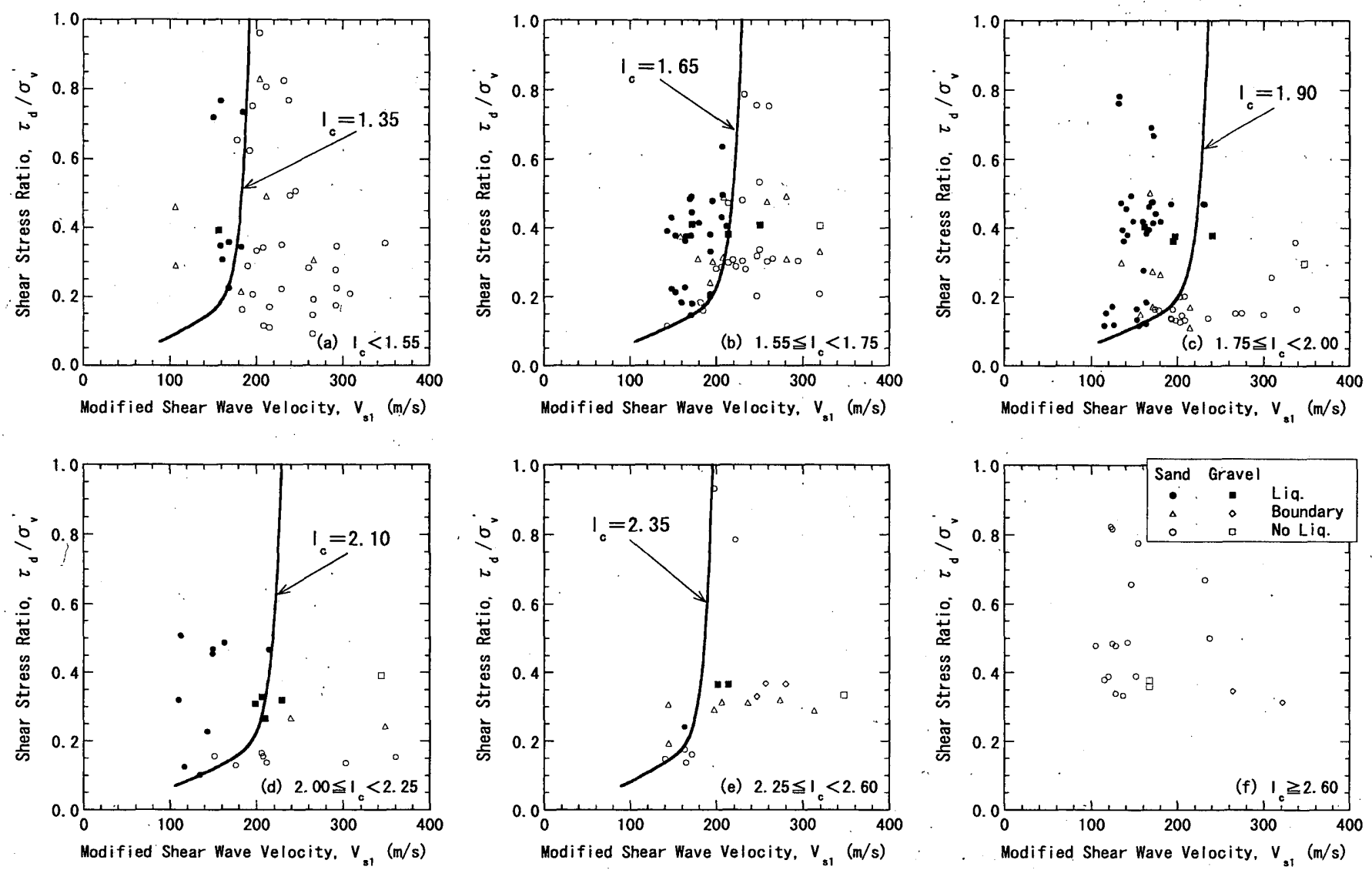

図 5. I。で分けた繰返しせん断応力比と換算せん断波速度の関係 


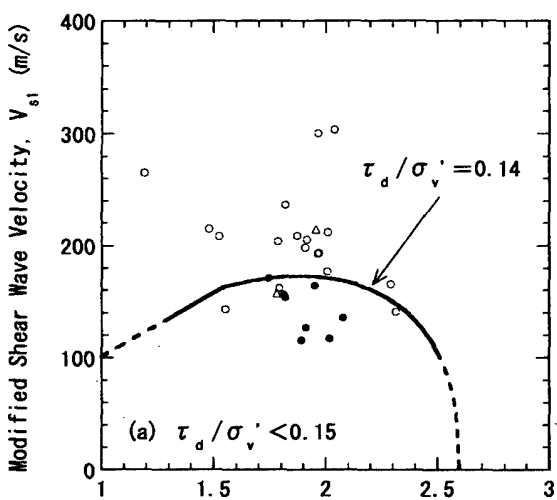

Soil Behaviour Type Index, I,

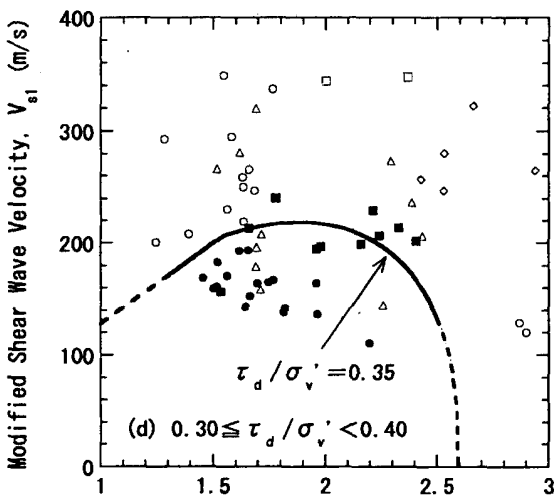

So il Behaviour Type Index, I,

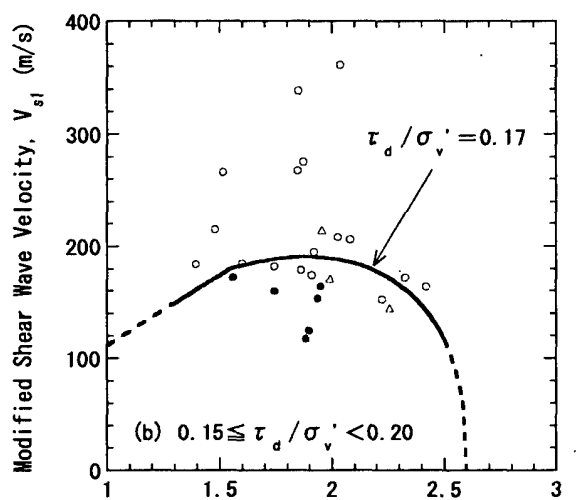

Soil Behaviour Type Index, I,

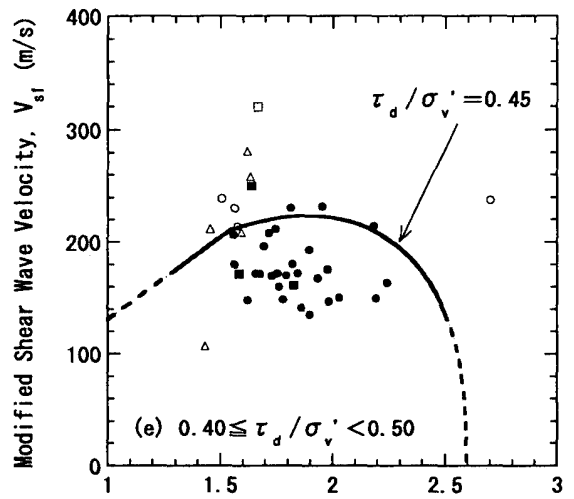

Soil Behaviour Type Index, I,

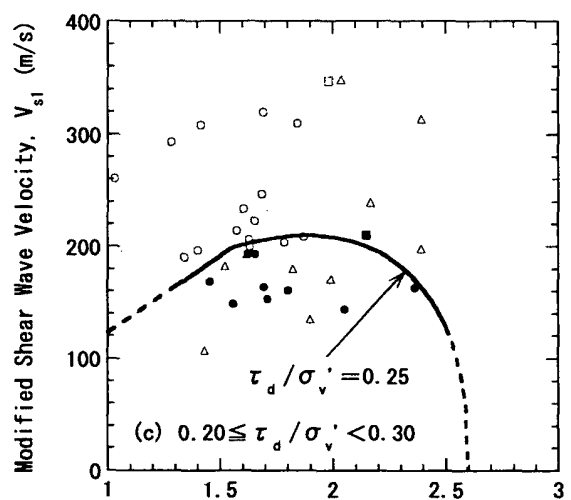

Soil Behaviour Type Index, I.

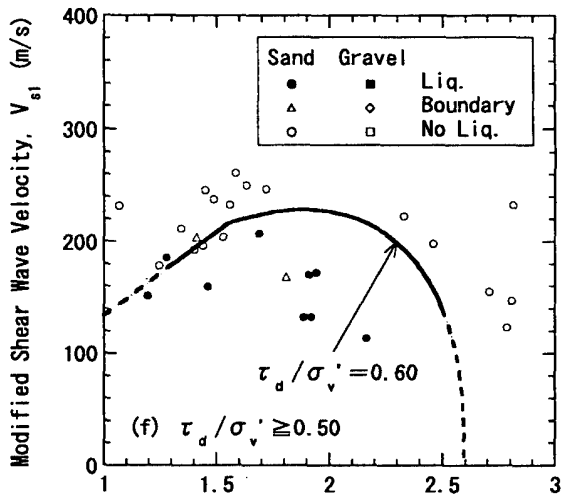

Soil Behaviour Type Index, I.

图6 繰返しせん断态力比で分けたと換算せん断波速度とI。の関俰

\section{4. せん断波速度による液状化強度予測}

\section{1 砂質土の限界換算せん断波速度}

（11）式で定義した限界換算せん断波速度を，換算せん断波速度と $\mathrm{I}_{\mathrm{c}}$ の関保に表示して図 7 に，繰返しせん断応力比と換算せん断波速 度の関係に表示して図 8 に示す。図 7 の横軸には，(4)式によってI。 から換算した細粒分含有率FC（\%)の軸を併記した。限界換算せん断 波速度 $\mathrm{V}_{\mathrm{s1cr}}$ は，（11）式に示したようにI $\mathrm{c}_{\mathrm{c}}$ が増えると大きくなる項 $\left(46.0 \mathrm{I}_{\mathrm{c}}-5.0\right)$ と, 小さくなる項 $\left[\mathrm{q}_{\mathrm{ta}} /\left\{1+\mathrm{F}\left(\mathrm{I}_{\mathrm{c}}\right)\right\}\right]^{0.4}$ の積で表さ

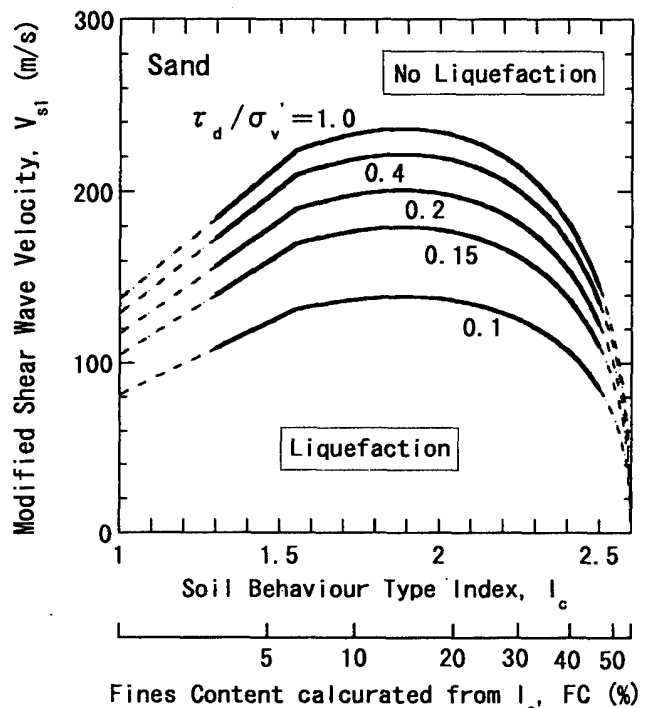

图 7 繰返しせん断応力比による限界換算せん断波速度の関係
れているため， I 1. 9 は (4) 式より $\mathrm{FC}=15$ (\%)に相当する。一般的には，細粒分含有率 が増える程 ( 波速度 $\mathrm{V}_{\mathrm{s} \text { cr }}$ が小さくなると考えられている。従って，FCが10\%程度 以下の砂のV ${ }_{\text {slcr }}$ が小さくなる傾向は, 既往の知見 ${ }^{7), 13), 14)}$ と異なってい る。砂に人工的に細粒分を混せた試料の液状化強度 ${ }^{48)}{ }^{49)}$ や，原位置 から採取した細粒分含有率の異なる砂試料の液状化強度 ${ }^{50)}$ は, 細粒 分の增加ととも一様に増加するのではなく，一度低下してから増加 寸る傾向が認められ，液状化強度が最小となる細粒分含有率FCは10

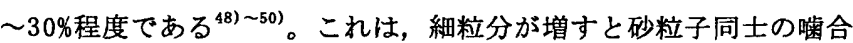

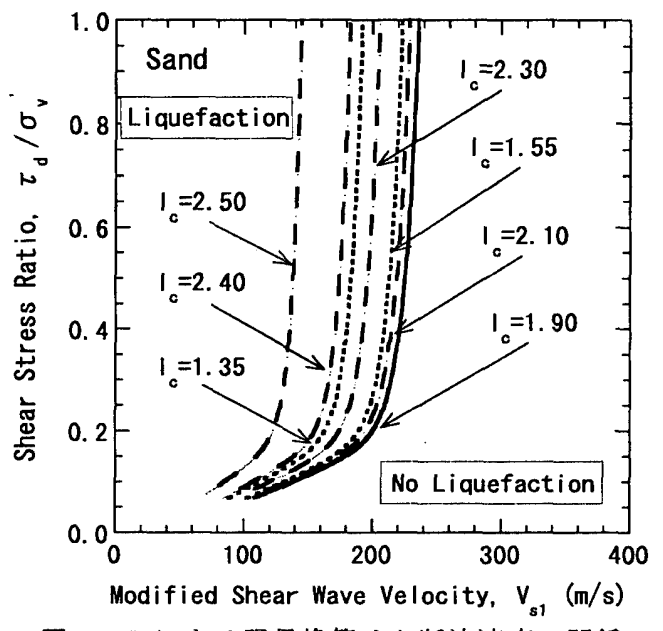

図 8 I による限界換算せん断波速度の関係 
いが薄れて液状化強度が一旦低下するが, さらに細粒分が増すと細 粒分粒子同士の噛合いや粘着力の影響で液状化強度が増加すると解 釈されている ${ }^{18), 49)}$ 。限界換算せん断波速度 $\mathrm{V}_{\mathrm{s} \text { cr }}$ が最大となる $\mathrm{I}_{\mathrm{c}}=1.9$ $(\mathrm{FC}=15 \%$ ）は, 液状化強度が最小となる上記範囲に含まれることか ら, 換算せん断波速度で評価した液状化強度に, 上記現象が顕著に 現れているものと推測される。

設計では，せん断波速度とともにせん断弾性係数を用いる。そこ で，次式から換算せん断弾性係数 $\mathrm{G}_{01}(\mathrm{MPa})$ を算出した。

$$
\mathrm{G}_{01}=\mathrm{G}_{0} /\left(98 / \sigma_{v}^{\prime}\right)^{0.5}=\rho_{\mathrm{i}} \cdot \mathrm{V}_{\mathrm{s} 1}^{2}
$$

ここで， $\mathrm{G}_{0}$ は初期せん断弹性係数 (MPa) である。湿潤密度 $\rho_{\mathrm{t}}=1.8$ $\left(\mathrm{g} / \mathrm{cm}^{3}\right)$ を仮定し, 図 7 の横軸を換算せん断弹性係数 $\mathrm{G}_{01}$ に変換した 関係を図 9 に示す。換算せん断弾性係数は，I。変化に対して敏感 に值を変えるとともに，換算せん断弾性係数の增減に対して絽返し せん断応力比が比較的緩やかに増減する関係となる。

\section{2 補正せん断波速度}

I が1.9 付近で限界換算せん断波速度が最大值を示すことから， $I_{c}=1.9$ を基準として換算せん断波速度を補正する。 $I_{c}$ が2.6以下の データに対し，換算せん断波速度 $\mathrm{V}_{s 1}(\mathrm{~m} / \mathrm{s})$ を $\mathrm{I}_{\mathrm{c}}$ に応じて補正した補 正せん断波速度 $V_{\mathrm{sa}}(\mathrm{m} / \mathrm{s})$ を次式で定義した。

$$
\mathrm{V}_{\mathrm{sa}}=\mathrm{V}_{\mathrm{s1}} \cdot\left(\mathrm{V}_{\mathrm{sler}(\mathrm{Ic}=1.9)} / \mathrm{V}_{\mathrm{sler(Ic)}}\right)
$$

ここで, $\mathrm{V}_{\mathrm{slcr}(\mathrm{lc}=1.9)}(\mathrm{m} / \mathrm{s})$ は $\mathrm{I}_{\mathrm{c}}=1.9$ の限界換算せん断波速度, $\mathrm{V}_{\mathrm{s} 1 \mathrm{cr}(\mathrm{Ic})}$ $(\mathrm{m} / \mathrm{s})$ はそのデータのI に基づく限界換算せん断波速度である。

地震時に地盤内に生じる繰返しせん断応力比 $\tau^{\prime}{ }_{\mathrm{d}} / \sigma_{\text {。 }}{ }^{\prime}$ と (13) 式に より補正した補正せん断波速度 $\mathrm{v}_{\mathrm{sa}}$ の関保を砂質土に関して図10に, 磁混じり土に関して図11に示す。図10,図11には $\mathrm{I}_{\mathrm{c}}=1.9$ における 砂質土の限界換算せん断波速度を実線で併記した。(13)式で定義し た補正せん断波速度 $\mathrm{V}_{\mathrm{sa}}$ を用いることで，砂質土に関してはI。よら ず，液状化・非液状化の境界を明瞭に示すことが出来る。一方，磷 混じり土に関しては境界線が右側にずれる傾向が認められる。この 原因として，粒径の大きな䃄混じり土ではせん断波が大きな磁を伝 わるため，土のせん断弾性係数に連動したせん断波速度よりも速く なることが考えられる ${ }^{51)}$ 。ポートアイランドで行われた凍結サンプ

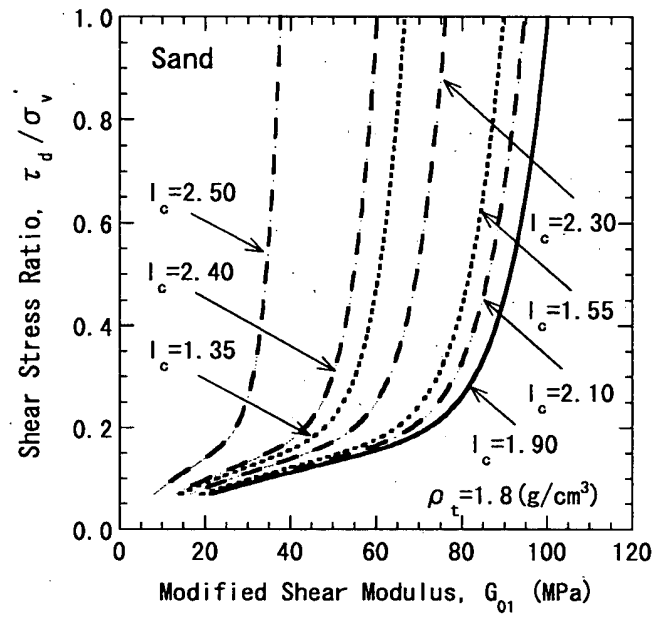

図 9 繰返しせん断応力比と換算せん断弹性係数の関係

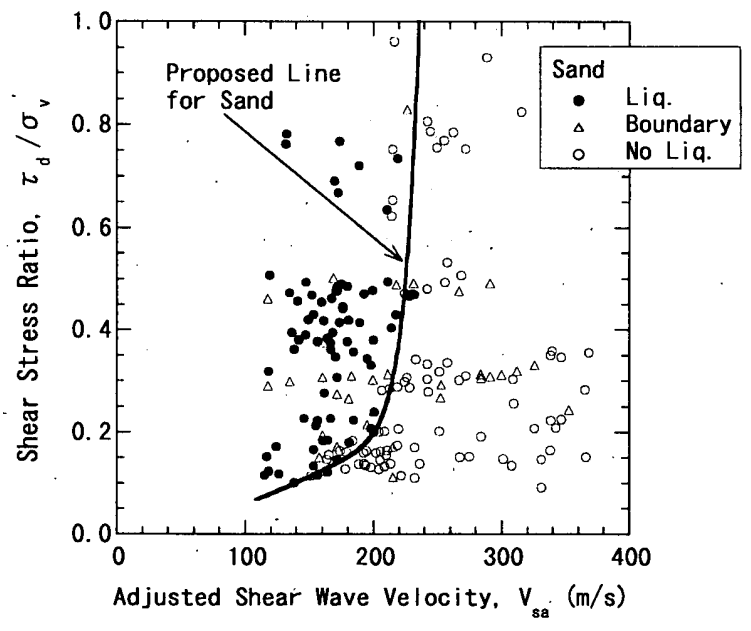

図10 繰返しせん断応力比と補正せん断波速度の関倸(砂質土)

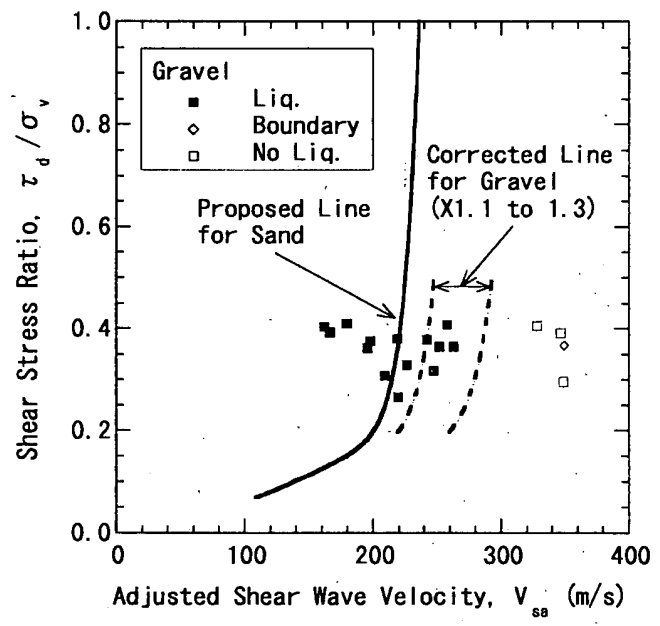

図11 繰返しせん断応力比々補正せん断波速度の関保(礫混じり土)

リング試料（表 1 に示したKWC地点近傍で赛施）の最大粒径は37.5〜 $101.6 \mathrm{~mm}$ であり ${ }^{52)}$, 文献51) から推定されるせん断波速度は砂質土の $1.1 \sim 1.3$ 倍程度大きくなるので, 砂質土の境界線の $1.1 \sim 1.3$ 倍の範 囲を図11に破線で併記した。磁混じり土の液状化・非液状化の境界 は，破線と概ね矛盾しないと判断されることから，磁混じり土では さらに補正が必要であると考えられる。ただし，図11に示したよう に, 磂混じり土のデータが砂質土のテータに比べて少なく, 磁混じ り土の液状化データ(回) と非液状化データ(口)の間が離れているた め, 本論文のデータで磁混じり土の境界線を検討するのは難しい。

なお，(13)式で定義される補正せん断波速度 $\mathrm{V}_{\mathrm{sa}}$ は，SCPT試験のせ ん断波速度, 先端抵抗および周面摩擦抵抗のみから得られ, 物理試 験結果をまったく必要としない。従って，SCPT試験のみで液状化強 度が推定できることになる。また，SCPT試験を行えば，先端抵抗と せん断波速度の両者で同時に，ある程度の精度で液状化強度予測が 出来ることになり，非常に有用であると考えられる。

5. まとめ

強震記録と液状化事例がそろっている地域でサイスミックコーン 貫入試験を実施した。地震時の繰返しせん断応力比と, サイスミッ クコーン貫入試験のせん断波速度およびI。関係を整理し，以下の 知見を得た。 
a）地震時の繰返しせん断灾力比と換算せん断波速度の関俰を $\mathrm{I}_{\mathrm{c}}$ で分 類すると, 砂質土の液状化・非液状化の境界が明瞭に示される。

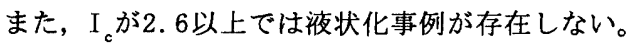

b) 液状化・非液状化の境界線は， I。が増えると右側へ移動するが, $\mathrm{I}_{\mathrm{c}}$ が1.9付近を境にして逆に左側へ移動する。

c） $\mathrm{I}_{\mathrm{c}}$ に基づき補正した補正せん断波速度 $\mathrm{V}_{\mathrm{sa}}$ を提案した。補正せん断 波速度を用いると, 砂質土の液状化・非液状化の境界が明瞭に示 される。

d）磁混じり土に関しては, 補正せん断波速度 $\mathrm{v}_{\mathrm{sa}}$ をさらに補正する必 要性が指摘できる。

e）サイスミックコーン貫入試験では, 先端抵抗とせん断波速度の両 者で同時に, ある程度の精度で液状化強度を予測できる。すなわ ち，2手法でクロスチェックが可能である。

最後に, 試験のために敷地を提供いただいた関係機関に謝意を表し ます。また, 気象庁, 運輸省港湾技術研究所（現独立行政法人港湾空 港技術研究所），建設省（現独立行政法人）建築研究所 -土木研究 所, 科学技術庁 (現文部科学省) 防災科学技術研究所, 神戸市, ESG 研究会, 鉄道総合技術研究所, 関西電力怢, 大阪ガス㑣が観測した強 震記録のデジタルデータを利用しました。記して謝意を表します。

\section{参考文献}

1) 日本建築学会：建築基礎構造設計指針，2001

2) 日本道路協会 : 道路橋示方書・同解説 V 耐震設計編, 2002

3) 鈴木康品, 時松孝次 : コーン貫入試験結果と凍結サンプリング試料の液状化强 度の関係，日本建築学会構造系論文集，第566号,pp. 81-88，2003.4

4) 鈴木康郘, 時松孝次, 古山田耕司 : 地震時の液状化事例とコーン貫入試䀦結果 の関係，日本建築学会構造系論文集，第571号, pp. 95-102, 2003.9

5) Suzuki, Y., Goto, S., Hatanaka, M. and Tokimatsu, K. : Correlation between strengths and penetration resistances for gravelly soils, Soils and Foundations, Vol.33, No.1, pp.92-101, 1993.3

6) Tokimatsu, K., Yamazaki, T. and Yoshimi, Y. : Soil liquefaction evaluations by elastic shear moduli, Soils and Foundations, Vol.26, No.1, pp.25-35, 1986.3

7) Tokimatsu, $K$. and Uchida, A. : Correlation between liquefaction resistance and shear wave velocity, Soils and Foundations, Vol.30, No.2, pp.33-42, 1990.6

8) Hatanaka, M., Uchida, A. and Suzuki, Y. : Correlation between undrained cyclic shear strength and shear wave velocity for gravelly soils, Soils and Foundations, Vol.37, No.4, pp.85-92, 1997.12

9) Stokoe, K. H. II, Roesset, J. M., Bierschwale, J. G. and Aouad, M. : Liquefaction potential of sands from shear wave velocity, Proceedings of 9th World Conference on Earthquake Engineering, Vol.III, pp.213-218, 1988

10) Robertson, P. K., Woeller, D. J. and Finn, W. D. L. : Seismic cone penetration test for evaluating liquefaction potential under cyclic loading, Canadian Geotechnical Journal, Vol.29, No.4, pp.686-695, 1992.8

11) Kayen, R. E., Mitchell, J. K., Seed, R. B., Lodge, A., Nishio, S. and Coutinho, R. : Evaluation of SPT-, CPT-, and shear wave-based methods for liquefaction potential assessment using Loma Prieta data, Proc., 4th Japan-U.S. Workshop on Earthquake Resistant Des. of Lifeline Fac. and Countermeasures for Soil Liquefaction, Tech. Rep. NCEER-92-0019, M. Hamada and T. D. O'Rourke, eds., Vol.1, National Center for Earthquake Engineering Research, Buffalo, pp.177-204, 1992

12) Lodge, A. L. : Shear wave velocity measurements for subsurface characterization, $\mathrm{Ph}$.D. dissertation, University of California, Berkeley, Calif, 1994

13) Andrus, R. D. and Stokoe, K. H. II : Liquefaction resistance based on shear wave velocity, Proceeding of NCEER Workshop on Evaluation of Liquefaction Resistance of Soils, Tech. Rep. NCEER-97-0022, National Center for Earthquake Engineering Research, Buffalo, pp.89-128, 1997

14) Andrus, R. D. and Stokoe, K. H. II : Liquefaction resistance of soils from shear-wave velocity, Journal of Geotechnical and Geoenvironmental Engineering, ASCE, Vol.126, No.11, pp. 1015-1025, 2000.11

15) 時松孝次, 大原淳良 : 講座「地盤の熱的問題」8.2凍結サンプリンク，土と基 碤, Vol. 38, No. 11, pp. 61-68, 1990.11

16) Tokimatsu, K. and Yoshimi, Y. : Empirical correlation of soil liquefaction based on SPT N-value and fines content, Soils and Foundations, Vol.23, No.4, pp.56-74, 1983.12

17) Robertson, P. K., Campanella, R. G., Gillespie, D. and Rice, A. : Seismic CPT to measure in situ shear wave velocity, Journal of Geotechnical Engineering, ASCE, Vol.112, No.8, pp. 791-803, 1986.8

18)鈴木康㽞, 笹尾光, 西謙治, 武居幸次郎 : サイスミックコーンとロータリー パーカッションドリルを併用した地盤調查システム, 日本建築学会技術報告
集, 第 1 号, pp. 180-185, 1995.12

19) 武藤清, 太田外気晴, 原昭夫, 丹羽正徳 : 相互相関関数によるS 波速度の測 定・解析，鹿島建設技術研究所年報，第20号，pp. 331-335，1972

20) Robertson, P. K. : Soil classification using the cone penetration test, Canadian Geotechnical Journal, Vol.27, No.1, pp.151-158, 1990.2

21) Robertson, P. K. and Fear, C. E. : Liquefaction of sands and its evaluation, Proceedings of the First International Conference on Earthquake Geotechnical Engineering, IS-TOKYO '95, Vol.3, pp.1253-1289, 1995

22)鈴木康品司, 時松孝次, 實松俊明 : コーン貫入試験結果と標準貫入試験から得ら れた地盤特性との関係, 日本建築学会構造系論文集, 第566号, pp. 73-80, 2003. 4

23)科学技術庁防災科学技術研究所：强震速報No. 41 1993年1月15日 平成 5 年 (1993年) 釧路沖地震, 1993.2

24) 石田寛, 佐ヶ木透, 丹羽正徳, 北川良和, 鹿沜俊英 : 釧路地方気象台の鉛直了 レ一地震観測記録に見られる表層地盤の增幅特性, 日本建築学会構造系論文 集, 第490号, pp. 91-100, 1996.12

25) 松永康男, 桜井博孝, 森田年一, 井合進 : 1993年釧路沖地震の港湾地域におけ 万強震記録，港湾技研資料，No. $777 ， 1994.6$

26)科学技術庁防災科学技術研究所：強震速報No. 44 1994年8月31日 国後島付近 の地震, 1994年10月4日 平成 6 年 (1994年) 北海道東方沖地震, 1994.12

27) 佐藤幸博, 宮田正史, 一井康二, 森田年一, 井合進 : 1994年北海道東方沖地震 の港浮地域における強震記録，港湾技研資料，No. 853，1996.12

28) Japanese Working Group on Effects of Surface Geology on Seismic Motion : Strong motion database, cooperative strong motion observation in Kushiro, Hokkaido, Japan, Association for Earthquake Disaster Prevention, 1997. 6

29) 松永康男, 桜井博孝, 森田年一, 井合進 : 1993年北海道南西沖地震の港湾地域 における强震記録，港湾技研資料，No. 778，1994.6

30) Nakamura, Y., Tomita, K., Tamogami, M., Hidaka, K., Saito, J. and Sato, S. : Strong acceleration and damage of 1993 Hokkaido Nansei-Oki Earthquake (quick report), JR Earthquake Information No.19b, Railway Technical Research Institute, 1993.6

31) 科学技術庁防災科学技術研究所 : 强震速報No. 46 1995年1月 17 日 平成 7 年 (1995年) 兵庫県南部地震, 1995.2

32) 建設省土木研究所 : 土木構造物における加速度強震記録 (No. 21), 土木研究所 裹報，第64号，1995. 6

33）佐藤幸博，一井康二，星野裕子，佐藤陽子，宮田正史，森田年一，井合進： 1995年兵庫県南部地震の港湾地域における強震記録, 港湾技研資料, No. 907, 1998. 6

34) 中村豊, 上半文昭, 井上英司 : 1995年兵庫県南部地震の地震動記録波形と分析 （II），J R 地震情報, No. 23d，1996.3

35) 日本建築学会兵庫県南部地震特別研究委員会特定研究課題1-SWG1, 日本建築学 会近畿支部耐震構造研究部会：1995年兵庫県南部地震強震記録資料集，日本建 築学会, 1996. 1

36) http://www.k-net.bosai.go.jp/k-net/

37）野津厚, 深澤清尊, 佐藤陽子, 玉井伸香, 菅野高弘：港湾地域強震観測年報 (1999\&2000)，港湾空港技術研究所資料，No. 1026，2002.3

38) 飛田溜，杉村義広 : 釗路地方気象台および釧路市内の地震動特性における表層 地盤の影響，1993年釧路沖地震に関する総合シンポジウム，日本建築学会地震 災害委員会, pp. 59-64, 1994

39) 鹿島：1993年1月 15 日釗路沖地震被害調查報告書, 1993.2

40)鹿島: 平成5年北海道南西沖地震被害調查報告書, 1993.8

41) Tokimatsu, K., Suzuki, Y. and Tamura, S. : Preliminary report on geotechnical aspects of Hokkaido-Nansei-Oki Earthquake of July 12, 1993, Performance of Ground and Soil Structures during Earthquakes, Special Volume for the 13th International Conference on Soil Mechanics and Foundation Engineering, pp.75-86, 1994.1

42) 鹿島 : 平成6年北海道東方神地震被害調查報告書, 1994.11

43) 鹿島 : 平成7年兵庫県南部地震被害調查報告書(第一報), 1995.2

44) 濱田政則, 䂸山龍二, 若松加寿江 : 1995年兵庫県南部地数液状化, 地盤変位及 び地盤条件, 地震予知総合研究振興会, 1995

45) 平成12年鳥取目西部地震災害緊急調查団: 平成12年鳥取県西部地震災害緊急調 查団報告, 地盤工学会・調查部, 2000.12

46) 大保直人, 鈴木康嘼: 鳥取県西部地震で液状化した安倍彦名団地の地盤評価, 第37回地盤工学研究発表会, pp. 1953-1954, 2002

47) 稲垣太浩, 福島勇治, 大保直人, 清田芳治, 鈴木康呞 : 境水道大橋で観測され た鳥取県西部地震記録の分析 (その 2) 地盤の評価, 土木学会第57回年次学術 講演会, Vol. I , pp. 1739-1740, 2002

48) 黄大振, 柳沢栄司, 菅野高弘: シルトを含む砂のせん断特性について, 土木学 会論文集, No. $463 /$ III-22, pp. 25-33, 1993.3

49)桑野二朗, 中澤博志, 杉原弘一, 矢部浩史 : 細粒分を含む砂の非排水繰返しせ 儿断強度, 第31回地盤工学研究発表会講演集, pp. 993-994, 1996

50) 伊藤周作, 兵動正幸: 不擋乱土の物理特性と液状化強度の関係について, 第33 回地盤工学研究発表会講演集, pp. 89-90, 1998

51) Tanaka, Y., Kokusho, T., Okamoto, T. and Kudo, K. : Evaluation of initial shear modulus of gravelly soil by laboratory test and PS-logging, Proceedings of the First International Conference on Earthquake Geotechnical Engineering, IS-TOKYO '95, Vol.1, pp.101-106, 1995

52) Hatanaka, M., Uchida, A. and Ohara, J. : Liquefaction characteristics of a gravelly fill liquefied during the 1995 Hyogo-ken Nanbu Earthquake, Soils and Foundations, Vol.37, No.3, pp.107-115, 1997.9

（2003年 7 月 10 日原稿受理，2004年 1 月 19 日採用決定） 